\title{
Analisa Pengaruh Trust dan Risk Berbasis Technology Acceptance Models (TAM) (Studi Kasus : Pengguna Google Drive)
}

\author{
Faustina Gunadi ${ }^{1}$ \\ Pasca Sistem Informasi Bisnis, STMIK LIKMI ${ }^{1}$ \\ Ir. H. Juanda No. 96, Bandung, 022 - $2502121^{1}$ \\ v.tinagunadi@yahoo.com ${ }^{1}$
}

Diterima : 28 Juni 2020. Disetujui: 13 Agustus 2020. Dipublikasikan: 15 Agustus 2020

\begin{abstract}
The development of information technology using the internet is increasing rapidly, many breakthroughs application are developed by leading providers. The feature application that provides convenience by integrating smart gadgets with the internet was developed by Google companies to reach wider consumers from all over the world. The author is interested in the phenomenon that has occurred since the existence of Google Drive, many users from all professions around the world and use these facilities to exchange information. In this phenomenon the author sees a Trust factor that arises so that the risk of exchanging information through the internet network seems to be accepted by Google Drive users. This research purpose is to prove the influence of these factors the author examines it using the Technology Acceptance Model (TAM) from Davis also included Trust and Risk, then validated with Structure Equation Model. The author determines the indicators of each variable to be tested on Google Drive users. Based on the results of Google Drive research, trust is dominant variable. However, the risk does not correlate to any of the variables because Google Drive user drivers are based on trust that influences behavior and benefits so as to shape the interests of Google Drive users. The research proven Trust is an influence variable of TAM for Google Drive users.
\end{abstract}

Keywords: tam; technology acceptance model; Google Drive; trust; risk; trust risk based on tam

Abstrak-- Perkembangan teknologi informasi dengan menggunakan internet semakin pesat, banyak terobosan yang dikembangkan oleh provider ternama. Fasilitas yang memberikan kemudahan dengan mengintegrasikan smart gadget dengan internet dikembangkan oleh perusahaan sekelas Google untuk menjangkau konsumen yang lebih luas dari seluruh dunia. Google Drive bertujuan untuk memudahkan pengguna Google di seluruh dunia untuk menyimpan dan mendistribusikan data dengan memberikan tanggung jawab kepada user penggunanya untuk mengatur akses atas file tersebut. Pada fenomena ini penulis melihat adanya faktor Trust yang muncul sehingga Risk bertukar informasi melalui jaringan internet diterima oleh para pengguna Google Drive. Penelitian ini bertujuan untuk membuktikan pengaruh faktor tersebut, penulis menguji menggunakan variabel Technology Acceptance Model (TAM) dari Davis dengan menambahkan Trust dan Risk, kemudian diukur pengaruh setiap variabel menggunakan Structural Equation Model. Penulis mengujikan indikator dari setiap variabel kepada pengguna Google Drive. Berdasarkan hasil penelitian Google Drive didapatkan variabel Trust berpengaruh signifikan. Akan tetapi, Risk tidak berkorelasi pada satupun variabel dikarenakan penggerak pengguna Google Drive didasari oleh kepercayaan yang mempengaruhi perilaku dan manfaat sehingga membentuk minat pengguna Google Drive. Penelitian membuktikan variabel Trust dapat menjadi variabel yang mempengaruhi pada TAM bagi para pengguna Google Drive.

Kata kunci: tam; technology acceptance model; Google Drive; trust; risk; trust risk berbasis tam

\section{PENDAHULUAN}

Perkembangan teknologi yang semakin pesat terbukti dari adanya aplikasi cloud storage. Teknologi selalu berkaitan dengan seberapa secure dan pertimbangan tingkatan risiko untuk menyimpan data pada cloud storage. Peneliti tertarik untuk mendalami minat pengguna dari Google Drive dikarenakan pada saat ini hampir semua kalangan menggunakan layanan Google Drive yang berguna untuk bertukar informasi dan tidak berbayar. Melihat fenomena minat pengguna ini memungkinkan Google Drive nantinya menjadi bank data dunia. Dikarenakan mulai terbukanya pengguna untuk menyimpan informasi pada Google
Drive yang merupakan cloud storage dari perusahaan Google.

TAM pada pengguna aplikasi mobile Mataharimall menunjukan Persepsi kemudahan penggunaan memiliki dampak positif terhadap persepsi kebermanfaatan. Persepsi kemudahan menggunakan dan manfaat memiliki dampak positif pada kecenderungan aplikasi digunakan oleh para pengguna. Dari hasil analisis dalam penelitian ini, dapat dilihat kecenderungan peningkatan penggunaan aplikasi oleh pengguna yang pernah menggunakan aplikasi tersebut [1].

Minat nasabah untuk menggunakan internet banking sebagai alat transaksi dipengaruhi oleh unsur - unsur yang dibahas dalam TRI-TAM, yakni 
trust, risk, perceived credibility memiliki pengaruh pada minat nasabah untuk menggunakan internet banking [2].

Berdasarkan beberapa penelitian diatas maka peneliti akan mengkaji lebih dalam terkait dengan Analisa Pengaruh Trust dan Risk Berbasis TAM terhadap Pengguna Google Drive. Peneliti merumuskan masalah yang diuji dengan menelaah hasil kuesioner pada pengguna Google Drive dengan menguji variabel Trust dan Risk berpengaruh terhadap variabel TAM dikarenakan dari beberapa penelitian sebelumnya perkembangan teknologi menghasilkan pengaruh terhadap para pengguna teknologinya dikarenakan manusia perlu beradaptasi sehingga dapat merespon penggunaan teknologi. Penelitian ini diharapkan dapat menunjukan fenomena pengguna Google Drive.

\section{LANDASAN TEORI}

Perkembangan teknologi informasi menjadi fokus utama pengembangan perusahaan perusahaan saat ini. Unsur yang terkandung dalam teknologi informasi adalah software, hardware, brainware. Faktor terpenting adalah brainware karena yang mengoperasikan teknologi informasi adalah brainware. Penggabungan teknologi informasi dengan internet membuka peluang besar bagi para developer aplikasi yang bergerak dalam bidang cloud computing.

Cloud computing, jika diartikan secara sederhana cloud berarti awan, sedangkan computing bearti proses melakukan input semuanya dilakukan secara online dikarenakan terkoneksi dengan internet [3] : "Paradigma penginputan dan penyimpanan baru, individu dan perusahaan dapat mengakses pada resources dengan hanya membayar biaya yang sedikit sesuai kebutuhan." Pengaplikasian cloud computing perlu memperhatikan tipe yang dipilih mengutip dari tipenya terdiri dari :

\section{Infrastructure as a service (IaaS)}

Membahas terkait dengan sumber virtualisasi seperti (computation, storage, and communication) yang disebut (IaaS). Penyediaan server berdasarkan permintaan yang disesuaikan dengan beberapa sistem informasi dan perangkat lunaknya. Infrastruktur ini sebagai lapisan utama sistem komputasi awan. Pengguna akan diberikan akses yang istimewa untuk beraktivitas pada server, seperti : memulai, menghentikan, menyesuaikan perangkat lunak yang diaplikasikan, konfigurasi ijin akses, dan aturan terkait firewall.

2. Platform as a service

Peran cloud sebagai penyedia infrastruktur yang menyediakan layanan komputasi dan menyimpan data haruslah di-design mudah dipelajari dengan harapan cloud dapat di program disebut platform as a service.

Umumnya platform menawarkan pengembangan, pembuatan, dan menggunakan aplikasi dan tidak perlu mengetahui berapa beragam prosesor atau memori yang digunakan aplikasi. Beberapa model pemprograman dan layanan khusus seperti : akses data, autentifikasi ditawarkan sebagai blok bangunan untuk aplikasi tersebut.

\section{Software as a service}

Berkenaan dengan perangkat lunak ini sebenarnya serupa dengan software yang diinstall secara local komputer. Pada SaaS ini yang ditawarkan adalah software yang serupa tapi sudah tersedia pada web sehingga memudahkan penggunanya untuk akses dan mendistribusikan data. Dari sisi pemeliharaan perangkat lunak dapat ditekan biayanya. SaaS pun menawarkan produktifitas bisnis dan sejalan dengan perkembangan memungkinkan pelanggan untuk menyesuaikan dan mengakses aplikasi sesuai permintaan.

Cloud computing berkembang dan saat ini terkenal dengan nama cloud storage. Perkembangan ini didukung dengan banyaknya aplikasi penyimpanan dengan media internet yang terkoneksi dengan server penyedia aplikasi, seperti google menyediakan aplikasi Google Drive. Konsep yang digunakan Google Drive adalah cloud storage.

Cloud Storage sebelumnya dikenal dengan nama virtual drive, namun memasuki masa cloud computing istilah tersebut lebih dikenal dengan sebutan cloud storage. Beberapa perusahaan penyedia cloud storage bermunculan dan beberapa cloud storage tersebut adalah : dropbox, onedrive, owncloud, Google Drive.

Google Drive adalah layanan penyimpanan data sharing milik Google yang diluncurkan 24 April 2012. Layanan ini merupakan ekstensi dari Google Docs dan menggantikan URL.docs.google.com dengan drive.google.com. Layanan yang diberikan oleh Google sebesar 15GB per user akun secara gratis. Nilai tambah yang diberikan Google Drive kepada usernya adalah data dapat diakses kapanpun dan dimanapun selama terkoneksi dengan internet. Google Drive memberikan layanan penyimpanan $15 \mathrm{~GB}$ untuk setiap akun user dan sangat mudah sharing data dari user kepada orang lain melalui email, user memiliki hak untuk membatasi file yang disharing [4].

Menurut Lai [5] perkembangan literatur berdasarkan perkembangan konsep dan aplikasi teknologi mempengaruhi perkembangan literatur 
dengan fokus pada aplikasi yang sedang trend di masyarakat. Perkembangannya literatur dimulai dari Theory of Reasonable Action (Fishbein dan Ajzen, 1975), Theory of Planned Behavior (Ajzen, 1985, 1991). Pada tahun 1989, dengan acuan dari Theory of Reasonable Action beberapa peneliti, yakni Davis, Bogozzi, dan Warshaw memperkenalkan Technology Acceptance Model (TAM). TAM dikembangkan kembali pada tahun 2000 oleh Venkatesh dan Davis menjadi TAM2. Setelah berjalan beberapa tahun Venkatesh dan Bala pada tahun 2008 mengembangkan menjadi TAM3. Pengembangan literatur tersebut dikarenakan teknologi terus berkembang dan banyak faktor yang mempengaruhi penerimaan saat user menggunakan teknologi tersebut.

Karya Ilmiah Fuad, Sangen, dan Albushari mengutip model TAM Davis, F.D. memperkenalkan Technology Acceptance Model pada karya ilmiah doktoralnya. Teori TAM terinspirasi dari TRA, TAM lebih spesifik fokus pada model penerimaan user atas teknologi informasi atau sistem informasi. Memodifikasi TAM dengan melihat penerimaan user atas penggunaan komputer. Modifikasi TAM tahun 1989 digambarkan oleh Davis pada Gambar 1 sebagai berikut [6]:

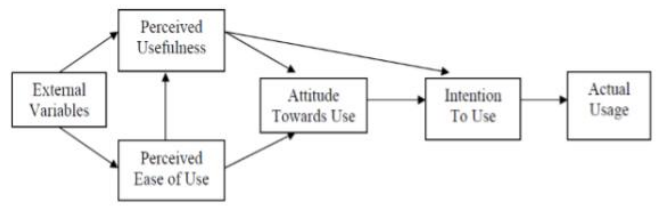

Gambar 1 Modifikasi Pertama Technology Acceptance Model

Davis melakukan riset dengan observasi kepada pengguna komputer berpengalaman berdasarkan acuan Perceived Ease of Use dan Perceived Usefulness masing - masing menghasilkan 14 skala, kemudian disimplifikasi oleh Davis menjadi masing masing 10 skala yang ditest-kan kepada pekerja IBM. Davis melakukan riset kembali dari 10 skala setelah dites menggunakan Spearmen-Brown menunjukan reliabilitas 0,97 ada 6 faktor yakni yang terkait dengan dua faktor utama TAM

Davis melakukan penelitian bersama Venkatesh pada tahun 1996 dengan dua faktor yaitu [7]: Perceived Usefulness dan Perceived Ease of Use ada pengaruh langsung terhadap Behavioral Intention yang mengeliminasi attitude dari model TAM.

Karya ilmiah Teo dan Noyes menelaah kembali penelitian David, F.D. dan Venkatesh pada tahun 2000 melakukan penelitian kembali terhadap TAM. Penelitian menghasilkan kegunaan sistem terbagi 3 poin [8]: pre-implementation, one month post - implementation, and three month post implementation. Teori pengembangan ini disebut TAM2.

Dua faktor utama pada TAM yaitu Perceived Usefulness dan Perceived Ease of Use terhadap pemanfaatan ATM yang diteliti oleh Nawawi menghasilkan didapatkan hubungan positif Daya Guna (perceived usefulness) pemanfaatan ATM (Automatic Teller Machine), hubungan negatif terhadap risiko (perceived risk) dikarenakan nasabah akan menggunakan ATM apabila risiko lebih rendah dalam melakukan transaksi sistem perbankan maka nasabah akan semakin sering memanfaatkan ATM, serta kepercayaan (trust) pada pemanfaatan ATM mendapatkan hasil sangat positif, setiap nasabah akan menggunakan ATM untuk transaksi [9], pada Gambar 2 :

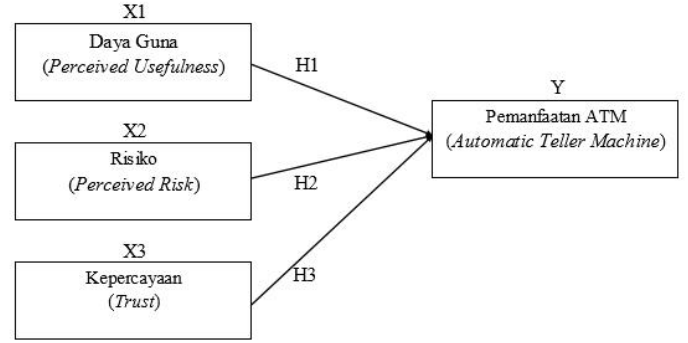

Gambar 2 Kerangka Penelitian Pemanfaatan ATM dengan variabel Perceived Usefulness, Perceived Risk, Trust

Vanitadyatama mengutip hasil penelitian Lui, Jamieson berkenaan dengan keterkaitan antara Trust dan Risk suatu aplikasi yang digunakan akan efektif apabila penggunanya percaya atas beberapa aspek pendukung, sehingga menciptakan penerimaan dari pengguna walaupun ada risiko yang muncul, faktor Trust dan Risk tersebut merupakan faktor penentu atas dua faktor [10]: Perceived Ease of Use dan Perceived Usefulness

Penelitian penerimaan situs Traveloka menggunakan metode penelitian TAM sebagai berikut [11] : Trust memiliki hubungan negatif dengan Perceived Risk, Perceived Usefulness. Sedangkan pengaruh positif terdapat pada Perceived Ease of Use terhadap Perceived Usefulness, kemudian Perceived Usefulness dan Perceived Ease of Use berpengaruh pada Intention to Use. Hasil pengujian tergambarkan pada Gambar 3 : 


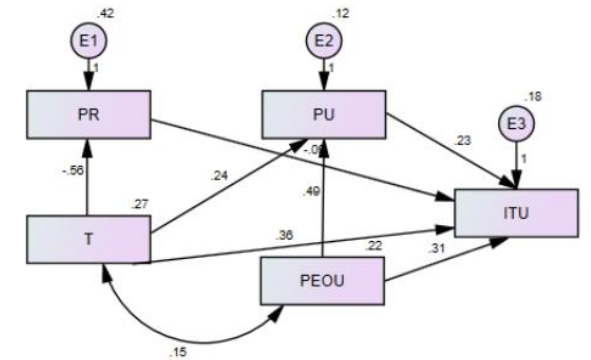

Gambar 3 Model Penelitian pengujian terakhir Trust and Perceived Risk berbasis TAM

Fokus penelitian utama yakni Perceived Risk dan Trust konsumen berpengaruh untuk membeli produk Jordan secara online. Selain itu, faktor yang mempengaruhi Trust pembeli saat membeli online adalah adanya lack dalam transaksi secara online. Trust sangat mempengaruhi behavioral intention dan perceived usefulness [12]. Keterkaitan Trust dan Risk ini dihubungkan oleh lack proses transaksi online pada Gambar 4 :

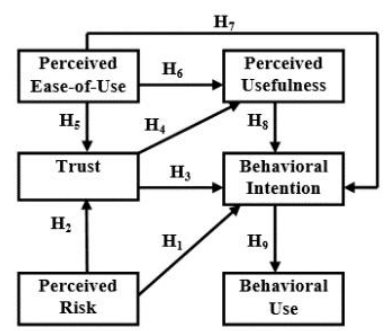

Gambar 4 Model Penelitian Integrating Perceived Risk and Trust with TAM

Keterkaitan Perceived Risk dengan Attitude Toward Using untuk pembelanjaan online di Kalimantan, memperoleh pengaruh akan tetapi tidak signifikan. Peneliti tidak memasukan variabel Trust pada penelitiannya sehingga bisa meningkatkan keterkaitan Attitude dengan Risk [6]. Seperti pada peneliti sebelumnya. Metode penelitian terdapat pada Gambar 5 :

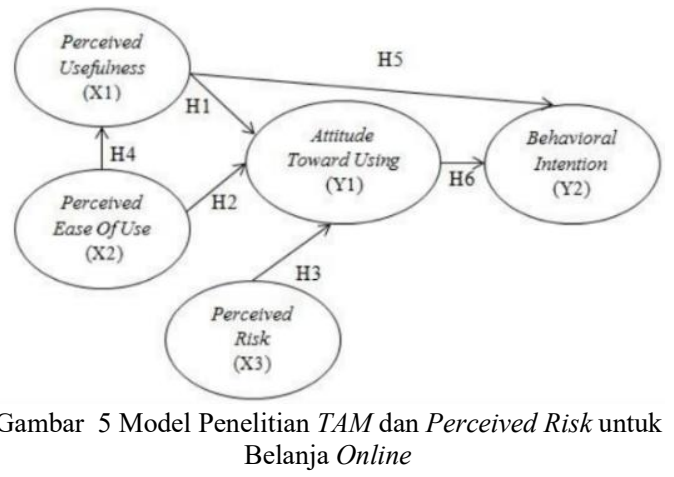

Berdasarkan teori TAM yang sudah diteliti oleh peneliti sebelumnya, peneliti tertarik untuk meneliti pengaruh Trust dan Risk terhadap TAM. Pengujian penelitian menggunakan uji validitas, uji reliabilitas, dan uji konstruk.

Teknik pengambilan sampel dibagi menjadi dua kategori, yaitu : probability sampling dan non probability sampling [13].

Ukuran sampel penelitian memiliki beberapa saran dari Roscoe pada tahun 1975 dalam kutipan [14]. Saran tersebut adalah :

a. Ukuran sampel yang layak adalah 30 sampai dengan 500

b. Apabila pembagian kategori sampel, misalkan pria dan wanita, maka masing masing kategori minimal 30

c. Apabila dalam korelasi ada analisa regresi ganda. Maka jumlah anggota sampel dikali 10 kali lipat dari jumlah variabel yang diteliti.

d. Penelitian eksperimen sederhana menggunakan kelompok eksperimen dan kelompok kontrol, jumlah sampel masing masing 10 sampai dengan 20.

Penarikan sampel dengan populasi yang besar menggunakan rumus Cochran, yang terdiri dari [15]:

$$
n_{0}=\frac{Z^{2} p q}{e^{2}}
$$

Keterangan rumus (1) sebagai berikut :

$n_{0} \quad=$ ukuran sampel

$\mathrm{Z}^{1}=1$ - tingkat kepercayaan, misal sebesar $95 \%$

e $\quad=$ tingkat ketepatan yang diinginkan

$\mathrm{p} \quad=$ proporsi yang diestimasi suatu atribut yang ada dalam suatu populasi

$$
\mathrm{q} \quad=1-\mathrm{p}
$$

Nilai Z didapatkan dalam tabel statistik yang berisi area dibawah kurva normal.

Jika nilai $\mathrm{p}$ tidak diketahui maka nilai $\mathrm{p}$ yang digunakan adalah 0,5 , dikarenakan pada penelitianpenelitian sebelumnya tidak ditemukan prevalensi tersebut maka diasumsikan sebanyak 50\% [16].

Skala Likert menunjukan data interval instrumen Likert terdiri dari empat, yaitu alternatif jawaban sangat setuju, setuju, tidak setuju, sangat tidak setuju, dengan memberikan nilai satu sampai dengan empat [17].

Pengujian validitas menggunakan perhitungan $\mathrm{r}$ hitung $\geq \mathrm{r}$ tabel dan menggunakan uji signifikansi $>0,05$

$$
r_{x y}=\frac{N \Sigma_{x y-(\Sigma x)}(\Sigma y)}{\sqrt{N \Sigma x^{2}-(\Sigma \mathrm{x})^{2}\left(N \Sigma y^{2}-(\Sigma y)^{2}\right.}}
$$

Keterangan rumus (2) sebagai berikut :

$\mathrm{r}_{\mathrm{xy}}=$ koefisien korelasi antara variabel $\mathrm{X}$ dan variabel Y

$\sum \mathrm{xy}=$ jumlah perkalian antara variabel $\mathrm{X}$ dan $\mathrm{Y}$

$\sum \mathrm{X}^{2}=$ jumlah dari kuadrat nilai $\mathrm{X}$

$\sum \mathrm{y}^{2}=$ jumlah dari kuadrat nilai $\mathrm{Y}$

$\left(\sum \mathrm{X}\right)^{2}=$ jumlah nilai $\mathrm{X}$ kemudian dikuadratkan

$\left(\sum \mathrm{y}\right)^{2}=$ jumlah nilai Y kemudian dikuadratkan 
Pengukuran tinggi dan rendahnya reliabilitas instrument menggunakan rumus Cronbach's Alpha reliabilitas yang tinggi ditunjukkan dengan nilai rxx mendekati angka 1. Rumus Cronbach's Alpha sebagai berikut :

$$
r_{11}=\left(\frac{n}{n-1}\right)\left(1-\frac{\Sigma \sigma_{t}^{2}}{\sigma_{t}^{2}}\right)
$$

Keterangan rumus (3) sebagai berikut :

r11 = reabilitas yang dicari

$\mathrm{n} \quad=$ jumlah item pertanyaan yang diuji

$\sum \sigma \mathrm{t} 2=$ jumlah varians skor tiap - tiap item

$\sigma \mathrm{t} 2=$ varians total

Pengkategorian untuk reabilitas ini adalah :

$<0.50=$ reabilitas rendah

$0.50-0.70=$ reabilitas moderat

$0.70-0.90=$ reabilitas tinggi

$>0.90=$ reabilitas sempurna

Pengujian struktural atau konstruk menggunakan Structural Equation Modelling (SEM). Ukuran sampel SEM tidak boleh sedikit berkisar antara 200 - 400 untuk model yang terdiri dari 10 - 15 indikator. Sampel dibawah 100 akan menghasilkan pengukuran SEM yang kurang baik terhadap Goodness of Fit. Sebuah model tidak mungkin memenuhi semua kriteria, yang terpenting kriteria yang dipenuhi lebih banyak dari yang tidak dipenuhi [18]. Model kecocokan dari kriteria : Chi Square, DF, GFI, AGFI, RMSEA, TLI, NFI, PNFI.

Pengumpulan data yang dilakukan oleh peneliti menggunakan kuesioner dengan alternatif jawaban mengguna skala Likert.

Perbedaan penelitian Trust Risk terhadap TAM dari penelitian sebelumnya adalah pada penelitian sebelumnya pengukuran Trust Risk hanya pada aplikasi perbankan dan online shop, sedangkan media pertukaran data menggunakan Google Drive perlu ditelaah mengingat pertukaran informasi semakin mudah dengan adanya teknologi dan hampir semua level profesi menggunakannya.

\section{METODE PENELITIAN}

Metode penelitian yang digunakan oleh peneliti adalah :

Tahapan yang dilakukan oleh peneliti pada Gambar 6 sebagai berikut :

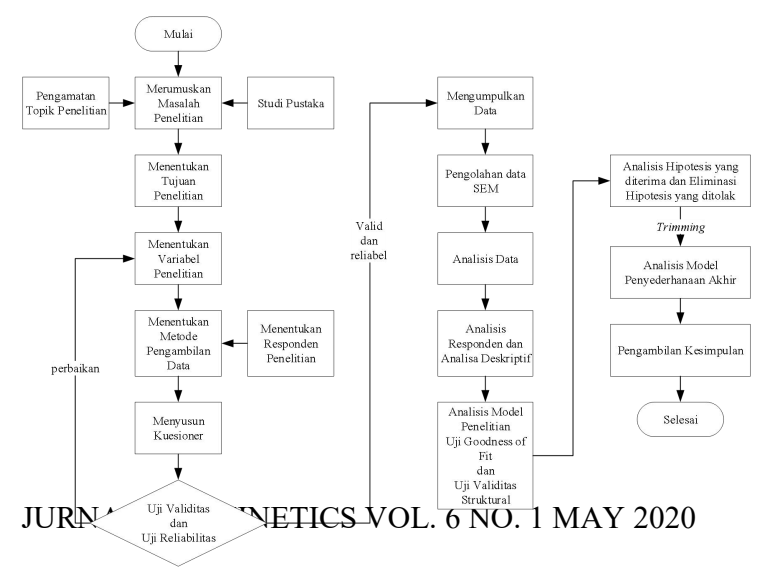

Gambar 6 Tahapan Penelitian

Model penelitian yang digunakan oleh peneliti adalah penggabungan TAM Davis tahun 1989 di tambahkan relasi variabel trust dan risk, sebagai berikut :

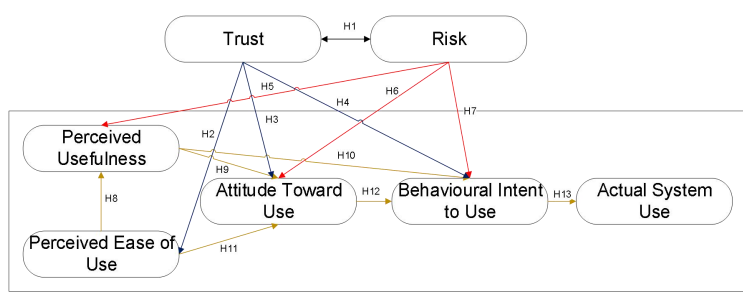

Gambar 7 Kerangka Pemikiran Peneliti

Berdasarkan gambaran kerangka pemikiran Trust dan Risk berpengaruh pada variabel bebas TAM lainnya, sebagai ada penyederhanaan variabel TAM lain setelah ditambahkan variabel Trust dan Risk. Variabel Trust dan Risk mewakili trend masa kini, semua manajemen sistem yang dipercaya handal harus mempertimbangkan risiko.

Setiap variabel Trust, Risk, dan TAM memiliki indikator pengujian yang menghasilkan 23 pertanyaan. Pertanyaan ditestkan terkebih dahulu kepada 30 orang, setelah divalidasi kemudian kuesioner disebarkan.

Penyebaran kuesioner dengan menyebarkan link Google Form di lingkungan kerja dan lingkungan akademi. Penentuannya ukuran sampel berdasarkan rumus Cochran didapatkan perkiraan sampel dengan jumlah minimal sebesar 96 responden

$$
\begin{aligned}
n_{0} & =(1,96)^{2}(0,5)(0,5) /(0,10)^{2} \\
& =3,8416(0,25) / 0,01 \\
& =0.96040,01=96,4=>96 \text { responden }
\end{aligned}
$$

Berdasarkan kuesioner yang sudah disebarkan melalui google form yang disebarkan pada orang dengan berbagai profesi, yaitu pelajar, wiraswasta, pekerja, guru dimulai tanggal 16 Maret 2020 sampai dengan 01 April 2020 didapatkan 118 responden. Berdasarkan perhitungan Cochran minimum 96, dikarenakan jumlah responden yang lebih tinggi dari minimum maka peneliti melakukan penelitian dari 118 responden.

Berikut pengembangan hipotesis berdasarkan kerangka penelitian, terdiri dari :

1. $\quad \mathrm{H} 1=$ Kepercayaan (Trust) pengguna Google Drive akan berpengaruh pada Risiko (Risk) penggunaan.

Perkembangan teknologi yang semakin cepat menuntut masyarakat sebagai 
pengguna untuk mengikuti perkembangan, terutama pengguna yang menggunakan perangkat pintar seperti : smartphone, tablet, laptop. Selain itu, aplikasi yang menjadi pelengkap dalam perangkat pintar akan mengedukasi penggunanya untuk mencoba menggunakan aplikasi tersebut, salah satu aplikasi untuk kemudahan penyimpanan dan sharing data untuk ponsel android adalah Google Drive. Pengguna smartphone android memiliki option untuk menyimpan data dengan sync ke Google Drive. Hal ini menunjukan pengguna sudah percaya terhadap aplikasi dan menerima risiko yang mungkin akan muncul. Hubungan trust dan risk terhadap aplikasi sudah diteliti sebelumnya oleh Ismulyaty tahun 2008, Lui and Jamieson tahun 2003. Berdasarkan uraian diatas maka disusunkan Hipotesis 1 .

2. $\mathrm{H} 2$ = Kepercayaan (Trust) pengguna Google Drive akan berpengaruh pada Kemudahan (Perceived Ease of Use) penggunaan Google Drive.

Pengamatan peneliti untuk beberapa pengguna google drive dikarenakan percaya akan aplikasi tersebut dan kemudahan aplikasi tersebut yang membuat penggunaan tertarik untuk menggunakannya. Hubungan trust dan perceived ease of use terhadap aplikasi sudah diteliti sebelumnya oleh Lui and Jamieson tahun 2003. Berdasarkan uraian diatas maka disusunkan Hipotesis 2.

3. $\mathrm{H} 3$ = Kepercayaan (Trust) pengguna Google Drive akan berpengaruh pada Perilaku (Attitude Toward Using) pengguna Google Drive.

Berkenaan dengan trust dan attitude toward using keduanya adalah kata sifat, akan tetapi trust seharusnya dapat menjadi pemicu untuk menimbulan respon perilaku pengguna. Hubungan trust dan attitude toward using sudah diteliti sebelumnya oleh Juhri tahun 2017 [19]. Berdasarkan uraian diatas maka disusunkan Hipotesis 3.

4. $\mathrm{H} 4=$ Kepercayaan (Trust) pengguna Google Drive akan berpengaruh pada Minat (Behavioral Intent to Use) pengguna Google Drive.

Berdasarkan pengamatan atas pengguna yang sudah percaya (trust) akan suatu aplikasi maka akan menggunakan aplikasi tersebut sebagai salah satu penunjang aktivitasnya, wujud dari minat (behavioral intent to use) tersebut akan muncul dari frekuensi dan lama aplikasi digunakan. Hubungan Trust dan Behavioral Intent to Use sudah diteliti sebelumnya oleh Juhri tahun 2017, Berdasarkan uraian diatas maka disusunkan Hipotesis 4.

5. $\mathrm{H} 5=$ Risiko (Risk) pengguna Google Drive akan berpengaruh pada Manfaat (Perceived Usefulness) penggunaan Google Drive.

Hubungan risiko atas penggunaan suatu sistem akan memunculkan manfaat yang tercermin dalam prinsip kehati - hatian pengguna saat menggunakan aplikasi. Hubungan ini sudah diteliti oleh Retnosari tahun 2015 [20] umumnya muncul pada penelitian aplikasi keuangan atau perbankan. Berdasarkan uraian diatas maka disusunkan Hipotesis 5.

6. $\mathrm{H} 6=$ Risiko (Risk) pengguna Google Drive akan berpengaruh pada Perilaku (Attitude Toward Using) pengguna Google Drive.

Risiko dapat mempengaruhi perilaku pengguna apabila didukung dengan adanya fakta atau kejadian berdasarkan pengalaman orang lain atau diri sendiri. Perilaku pengguna akan berbeda ketika mengalami langsung risiko dan tidak mengalami langsung risiko. Hubungan ini sudah diteliti oleh Ismulyaty, Siswantini tahun 2013, Retnosari tahun 2015, umumnya muncul pada penelitian aplikasi keuangan atau perbankan. Berdasarkan uraian diatas maka disusunkan Hipotesis 6.

7. $\mathrm{H7}=$ Risk (Risk) pengguna Google Drive akan berpengaruh pada Minat (Behavioral Intent to Use) pengguna Google Drive.

Risiko mempengaruhi minat pengguna apabila risiko merugikan pengguna maka pengguna besar kemungkinan tidak berminat menggunakan aplikasi tersebut. Akan tetapi, apabila risiko tersebut adalah residual risk dan dapat diterima pengguna besar kemungkinan minat menggunakan ada Kusumawati, Rikumahu tahun 2019 [21]. Berdasarkan uraian diatas maka disusunkan Hipotesis 7.

8. $\mathrm{H} 8=$ Kemudahan (Perceived Ease of Use) pengguna Google Drive akan berpengaruh pada Manfaat (Perceived Usefulness) penggunaan Google Drive.

Kemudahan suatu aplikasi akan memberikan manfaat dari sisi nilai tambah waktu dan fleksibilitas bagi penggunanya. Hubungan kemudahan dan manfaat sudah diteliti oleh Davis tahun 1989, Yani tahun 2018 [22]. Berdasarkan uraian diatas maka disusunkan Hipotesis 8.

9. $\mathrm{H} 9=$ Manfaat (Perceived Usefulness) pengguna Google Drive akan berpengaruh pada Perilaku (Attitude Toward Using) pengguna Google Drive. 
Hubungan manfaat dan perilaku akan suatu aplikasi biasanya muncul apabila aplikasi tersebut memang digunakan oleh pengguna secara terus menerus dan menunjang aktivitas pengguna. Selain itu, sisi manfaat biasanya akan menunjukan efektifitas penggunaan aplikasi bagi penggunanya. Hubungan manfaat dan perilaku sudah diteliti oleh Davis tahun 1989, Dewi tahun 2017. Berdasarkan uraian diatas maka disusunkan Hipotesis 9.

10. $\mathrm{H} 10=$ Manfaat (Perceived Usefulness) pengguna Google Drive akan berpengaruh pada Minat (Behavioral Intent to Use) pengguna Google Drive.

Hubungan manfaat dan minat pengguna suatu aplikasi menunjukan aplikasi yang memberikan nilai tambah bagi penggunanya akan diminati oleh pengguna lain, Hubungan manfaat dan minat pengguna sudah diteliti oleh Davis tahun 1989, Kusumawati, Rikumahu tahun 2019. Berdasarkan uraian diatas maka disusunkan Hipotesis 10.

11. H11 = Kemudahan (Perceived Ease of Use) pengguna Google Drive akan berpengaruh pada Perilaku (Attitude Toward Using) pengguna Google Drive.

Pada umumnya perilaku pengguna akan suatu aplikasi akan positif apabila aplikasi tersebut mudah untuk diaplikasikan oleh penggunanya. Selain itu, aplikasi yang diaplikasikan ke dalam perangkat pintar lebih diminati oleh pengguna karena selain mudah dibawa, diakses, ruang dan waktu tidak menjadi batasan kemudahan aplikasi tersebut. Hubungan kemudahan dan perilaku pengguna sudah diteliti oleh Davis tahun 1989, Jogiyanto tahun 2004 [23]. Berdasarkan uraian diatas maka disusunkan Hipotesis 11.

12. $\mathrm{H} 12=$ Perilaku (Attitude Toward Using) pengguna Google Drive akan berpengaruh pada Minat (Behavioral Intent to Use) pengguna Google Drive.

Perilaku dan Minat pengguna saling mendukung saat pengguna yang menunjukan respon atau perilaku positif akan tercermin dari minat pengguna untuk menggunakan dan merekomendasikan aplikasi tersebut kepada pengguna lainnya. Selain itu, dari intensitas dan banyaknya data yang dikoneksikan akan terlihat minat pengguna akan sistem tersebut. Hubungan kemudahan dan perilaku pengguna sudah diteliti oleh Davis tahun 1989, Juhri, Dewi tahun 2017. Berdasarkan uraian diatas maka disusunkan Hipotesis 12.
13. $\mathrm{H} 13=$ Minat (Behavioral Intent to Use) pengguna Google Drive akan berpengaruh pada Penggunaan Sistem (Actual System Use) Google Drive.

Minat pengguna mendorong pengaplikasian sistem oleh pengguna. Minat menjadi ujung dari implementasi penggunaan suatu aplikasi Hubungan minat dan penggunaan sistem ini. Hubungan minat dan penggunaan saling berkaitan dalam penelitian Davis tahun 1989 Davis \& Venkatesh tahun 1996 dan tahun 2000, Gardner tahun 2004 [24], Wibowo tahun 2017 [25], Venkatesh \& Bala tahun 2008 [5]. Berdasarkan uraian diatas maka disusunkan Hipotesis 13.

Berdasarkan model dan hipotesis penelitian yang sudah dideskripsikan oleh peneliti, maka peneliti membuat kuesioner berdasarkan indikator yang berpengaruh untuk setiap variabel yang akan diuji, indikator tersebut pada Tabel I adalah :

\section{TABEL I VARIABEL, DEFINISI, INDIKATOR YANG} DITELITI 


\begin{tabular}{|c|c|c|}
\hline Variabel & Definisi & Indikator \\
\hline $\begin{array}{l}\text { Perceived } \\
\text { Ease of Use } \\
\text { (PEOU) } \\
\text { Davis (1989) }\end{array}$ & $\begin{array}{l}\text { Pengguna } \\
\text { mendapatkan nilai } \\
\text { tambah dari } \\
\text { sistem baik } \\
\text { kemudahan untuk } \\
\text { digunakan }\end{array}$ & $\begin{array}{l}\text { 1. Mudah dimengerti } \\
\text { dan dipelajari } \\
\text { (PEOU1) } \\
\text { 2. Fleksibel (PEOU2) } \\
\text { 3. Mengontrol pekerjaan } \\
\text { (PEOU3) } \\
\text { 4. Mudah dalam } \\
\text { pengaplikasian } \\
\text { (PEOU4) }\end{array}$ \\
\hline $\begin{array}{l}\text { Perceived } \\
\text { Usefulness } \\
(P U) \\
\text { Davis (1989) }\end{array}$ & $\begin{array}{l}\text { Penggunaan } \\
\text { sistem menaikan } \\
\text { kinerja dan } \\
\text { efektifitas kinerja } \\
\text { karena proses } \\
\text { menjadi optimal }\end{array}$ & $\begin{array}{l}\text { 1. Meningkatkan } \\
\text { performa kerja (PU1) } \\
\text { 2. Menjadikan pekerjaan } \\
\text { efektif (PU2) } \\
\text { 3. Produktifitas user } \\
\text { meningkat (PU3) } \\
\text { 4. Hasil yang akurat } \\
\text { (PU4) } \\
\text { 5. Memenuhi kebutuhan } \\
\text { (PU5) } \\
\text { 6. Mengurangi Non } \\
\text { Value Added Activity } \\
\text { (PU6) }\end{array}$ \\
\hline $\begin{array}{l}\text { Attitude } \\
\text { Toward Use } \\
\text { (ATT) } \\
\text { Davis (1989) }\end{array}$ & $\begin{array}{l}\text { Unsur yang terkait } \\
\text { dengan sikap } \\
\text { pengguna }\end{array}$ & $\begin{array}{l}\text { 1. Penerimaan seseorang } \\
\text { terhadap teknologi } \\
\text { informasi } \\
\text { menimbulkan } \\
\text { antusiasme (ATT1) } \\
\text { 2. Penerimaan seseorang } \\
\text { terhadap teknologi } \\
\text { informasi } \\
\text { menimbulkan rasa } \\
\text { senang (ATT2) } \\
\text { 3. Penerimaan seseorang } \\
\text { terhadap teknologi } \\
\text { informasi } \\
\text { menimbulkan } \\
\text { keinginan } \\
\text { menggunakan secara } \\
\text { mandiri (ATT3) }\end{array}$ \\
\hline $\begin{array}{l}\text { Behavioral } \\
\text { Intent to Use } \\
\text { (IU) } \\
\text { Davis (1989) }\end{array}$ & $\begin{array}{l}\text { Pengguna akan } \\
\text { kembali lagi untuk } \\
\text { menggunakan } \\
\text { aplikasi }\end{array}$ & $\begin{array}{l}\text { 1. Persepsi dan sikap } \\
\text { positif (IU1) } \\
\text { 2. Niat pengguna } \\
\text { mengakses aplikasi } \\
\text { (IU2) }\end{array}$ \\
\hline $\begin{array}{l}\text { Actual System } \\
\text { Use (AU) } \\
\text { Davis (1989) }\end{array}$ & $\begin{array}{l}\text { Penggunaan } \\
\text { sistemnya secara } \\
\text { realistis }\end{array}$ & $\begin{array}{l}\text { 1. Perilaku penggunaan } \\
\text { sistem dalam } \\
\text { frekuensi (AU1) } \\
\text { 2. Perilaku penggunaan } \\
\text { sistem dalam waktu } \\
\text { (AU2) }\end{array}$ \\
\hline $\begin{array}{l}\text { Trust (TR) } \\
\text { Mayer (1995) }\end{array}$ & $\begin{array}{l}\text { Pengguna leluasa } \\
\text { untuk menyimpan } \\
\text { datanya pada } \\
\text { provider cloud }\end{array}$ & $\begin{array}{l}\text { 1. Ability (TR1) } \\
\text { 2. Benevolence (TR2) } \\
\text { 3. Integrity (TR3) }\end{array}$ \\
\hline $\begin{array}{l}\text { Risk (R) } \\
\text { Pavlou } \\
(2003: 77)\end{array}$ & $\begin{array}{l}\text { Potensi yang akan } \\
\text { muncul pada } \\
\text { waktu tertentu } \\
\text { dikarenakan satu } \\
\text { atau lain hal dan } \\
\text { menimbulkan } \\
\text { kerugian }\end{array}$ & $\begin{array}{ll}\text { 1. } & \text { Adanya risiko } \\
\text { tertentu (R1) } \\
\text { 2. } & \text { Mengakibatkan } \\
\text { kerugian (R2) } \\
\text { 3. } & \text { Persepsi beresiko } \\
& \text { (R3) }\end{array}$ \\
\hline
\end{tabular}

\section{HASIL DAN PEMBAHASAN}

Hasil penelitian dari 118 responden di uji validitas, uji realibilitas, dan uji konstruknya menggunakan metode pengukuran : Pearson, Cronbach Alpha, SEM

Berdasarkan jumlah respon kuesioner online yang masuk sejumlah 118 responden terdiri dari :

1. Jumlah 118 responden terdiri dari : responden wanita 64 orang $(54,24 \%)$, responden pria 54 orang $(45,76 \%)$. Berdasarkan jenis kelamin kuesioner banyak direspon oleh responden wanita

2. Jumlah 118 responden terdiri dari beberapa kategori usia, yaitu : responden dengan usia $<20$ tahun sebanyak 23 orang $(19,49 \%)$, responden dengan usia $20-30$ tahun sebanyak 26 orang $(22,03 \%)$, responden dengan usia 30 - 40 tahun sebanyak 53 orang $(44,92 \%)$, responden dengan usia $40-$ 50 tahun sebanyak 10 orang $(8,47 \%)$, responden dengan usia $>50$ tahun sebanyak 6 orang $(5,08 \%)$

3. Jumlah 118 responden terdiri dari beberapa profesi pekerjaan, yaitu : responden dengan profesi sebagai mahasiswa / pelajar sebanyak 26 orang $(22,03 \%)$, responden dengan profesi sebagai pegawai sebanyak 61 orang $(51,69 \%)$, responden dengan profesi sebagai pengajar sebanyak 3 orang $(2,54 \%)$, responden dengan profesi sebagai wiraswasta sebanyak 28 orang $(23,73 \%)$

Berdasarkan data profil responden didapatkan bahwa pengguna yang menggunakan Google Drive adalah usia produktif dari usia $<20$ tahun, usia 20 - 30 tahun, usia 30 - 40 tahun; dengan profesi responden pengguna Google Drive mayoritas dari pekerja, wiraswasta, dan mahasiswa / pelajar.

Pengujian uji validitas atas semua indikator dalam variabel yang diteliti didapatkan hasil keseluruhan indikator diatas $>0,05$ serta rhitung $>$ rtabel. Setelah didapatkan hasil semua indikator valid, peneliti melanjutkan pengujian reliabilitas.

Pada pengujian reliabilitas didapatkan hasil berikut : hasil Cronbach Alpha: PEOU (0,919), PU $(0,935), \operatorname{ATT}(0,885)$, IU $(0,837)$, AU $(0,934)$, TR $(0,912)$, R $(0,769)$ lebih besar dari standar yang ditentukan yaitu 0,6. Dengan demikian model instrumen yang diuji tersebut reliabel.

Pengujian model penelitian pada TABEL II menggunakan AMOS untuk melakukan pengujian konstruk atas hipotesis yang dibuat oleh peneliti. Hasil pengujian sebagai berikut : 
TABEL II Hasil Uji Regression Weight Model Penelitian

\begin{tabular}{|c|c|c|c|c|c|c|c|}
\hline \multicolumn{3}{|c|}{ Variabel } & $\begin{array}{c}\text { Estima } \\
\text {-te }\end{array}$ & S.E. & C.R. & $\mathrm{P}$ & Keterang- \\
\hline $\mathrm{TR}$ & $<>$ & $\mathrm{R}$ & $-0,031$ & 0,028 & $-1,112$ & 0,266 & $\begin{array}{l}\text { H1 } \\
\text { Ditolak }\end{array}$ \\
\hline $\begin{array}{l}\mathrm{PE} \\
\mathrm{OU}\end{array}$ & $<-$ & $\mathrm{TR}$ & 0,525 & 0,094 & 5,561 & $* * *$ & $\begin{array}{l}\mathrm{H} 2 \\
\text { Diterima }\end{array}$ \\
\hline $\begin{array}{l}\text { AT } \\
\text { T }\end{array}$ & $<-$ & $\mathrm{TR}$ & 0,405 & 0,111 & 3,637 & $* * *$ & $\begin{array}{l}\text { H3 } \\
\text { Diterima }\end{array}$ \\
\hline IU & $<-$ & $\mathrm{TR}$ & 0,596 & 0,117 & 5,105 & $* * *$ & $\begin{array}{l}\mathrm{H} 4 \\
\text { Diterima }\end{array}$ \\
\hline PU & $<-$ & $\mathrm{R}$ & $-0,034$ & 0,067 & $-0,513$ & 0,608 & $\begin{array}{l}\text { H5 } \\
\text { Ditolak }\end{array}$ \\
\hline $\begin{array}{l}\text { AT } \\
\text { T }\end{array}$ & $<-$ & $\mathrm{R}$ & 0,078 & 0,095 & 0,817 & 0,414 & $\begin{array}{l}\text { H6 } \\
\text { Ditolak }\end{array}$ \\
\hline IU & $<-$ & $\mathrm{R}$ & 0,1 & 0,094 & 1,068 & 0,286 & $\begin{array}{l}\text { H7 } \\
\text { Ditolak }\end{array}$ \\
\hline $\mathrm{PU}$ & $<-$ & $\begin{array}{l}\mathrm{PE} \\
\mathrm{OU}\end{array}$ & 0,734 & 0,083 & 8,878 & $* * *$ & $\begin{array}{l}\text { H8 } \\
\text { Diterima }\end{array}$ \\
\hline $\begin{array}{l}\text { AT } \\
\mathrm{T} \\
\end{array}$ & $<-$ & PU & 0,628 & 0,179 & 3,517 & $* * *$ & $\begin{array}{l}\text { H9 } \\
\text { Diterima }\end{array}$ \\
\hline IU & $<-$ & PU & 0,074 & 0,127 & 0,581 & 0,561 & $\begin{array}{l}\text { H10 } \\
\text { Ditolak }\end{array}$ \\
\hline $\begin{array}{l}\mathrm{AT} \\
\mathrm{T} \\
\end{array}$ & $<-$ & $\begin{array}{l}\mathrm{PE} \\
\mathrm{OU} \\
\end{array}$ & $-0,017$ & 172 & $-0,1$ & 0,92 & $\begin{array}{l}\text { H11 } \\
\text { Ditolak }\end{array}$ \\
\hline $\mathrm{IU}$ & $<-$ & $\begin{array}{l}\mathrm{AT} \\
\mathrm{T}\end{array}$ & 0,35 & 0,121 & 2,893 & 0,004 & $\begin{array}{l}\text { H12 } \\
\text { Diterima }\end{array}$ \\
\hline $\mathrm{AU}$ & $<-$ & $\mathrm{IU}$ & 1,002 & 0,109 & 9,174 & $* * *$ & $\begin{array}{l}\text { H13 } \\
\text { Diterima }\end{array}$ \\
\hline
\end{tabular}

Berdasarkan TABEL II ada beberapa variabel yang relasinya tidak dapat diterima setelah dilakukan pengujian, Hipotesis tersebut adalah :

1. H1 tidak ada korelasi antara Trust dengan Risk

2. H5 tidak ada korelasi antara Risk dengan Perceived Usefulness

3. H6 tidak ada korelasi antara Risk dengan Attitude Toward Using

4. H7 tidak ada korelasi antara Risk dengan Behavioral Intention to Use

5. H10 tidak ada korelasi antara Perceived Usefulness dengan Behavioral Intention to Use

6. H11 tidak ada korelasi antara Perceived Ease of Use dengan Attitude Toward Using

Hasil korelasi setelah pengujian menunjukkan 6 dari 13 hipotesis yang diteliti tidak berhubungan setelah diuji menggunakan hasil 118 responden.

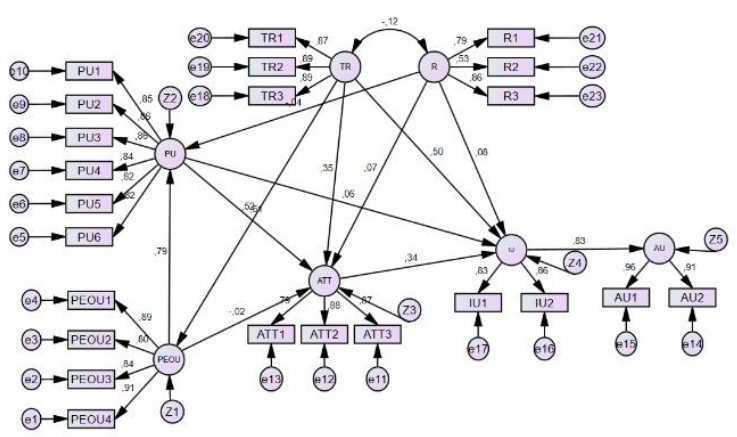

Gambar 8 Pengujian Struktural Model Penelitian
Berdasarkan hasil uji model penelitian menggunakan program AMOS, didapatkan hasil yang dijabarkan pada TABEL III :

TABEL III HASIL UJI MODEL PENELITIAN

\begin{tabular}{|c|c|c|c|}
\hline $\begin{array}{c}\text { Kriteria } \\
\text { Model sesuai } \\
(\text { Fit }) \\
\end{array}$ & $\begin{array}{l}\text { Hasil } \\
\text { Uji }\end{array}$ & $\begin{array}{c}\text { Acceptance } \\
\text { Level }\end{array}$ & Interpretasi \\
\hline Chi Square & 252,365 & 527,053 & $\begin{array}{l}\text { Hasil tabel chi square dari } \\
\text { DF } 217 \text { dengan } \\
\text { probability } 0,05 \text { adalah } \\
\text { 252,365. Hasil uji lebih } \\
\text { rendah sehingga model fit }\end{array}$ \\
\hline $\begin{array}{l}\text { Derajat } \\
\text { Bebas, DF }\end{array}$ & 217 & & \\
\hline CMIN/DF & 2,429 & $\begin{array}{l}<2 \quad \text { (Byrne, } \\
1998) \\
<5 \text { (Wheaton, } \\
1977)\end{array}$ & $\begin{array}{l}\text { Model Fit karena nilai DF } \\
\text { masih dibawah } 5 \text { jika } \\
\text { mengikuti teori Wheaton }\end{array}$ \\
\hline GFI & 0,745 & $\begin{array}{lll}\text { (Un Fit) } & 0 \\
\text { s.d. } 1 \text { (Fit) } & \end{array}$ & $\begin{array}{l}\text { Model Fit karena hasil } \\
\text { GFI masih ada di dalam } \\
\text { range }\end{array}$ \\
\hline AGFI & 0,675 & 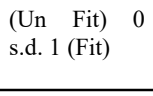 & $\begin{array}{l}\text { Model Fit karena hasil } \\
\text { GFI masih ada di dalam } \\
\text { range }\end{array}$ \\
\hline RMSEA & 0,111 & $\begin{array}{l}\leq 0,08 \\
\text { (Browne dan } \\
\text { Curdeck , } \\
1993 \text { ) } \\
\end{array}$ & RMSEA masih tinggi \\
\hline TLI & 0,846 & 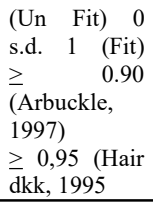 & $\begin{array}{l}\text { Model Fit karena hasil } \\
\text { TLI masih ada di dalam } \\
\text { range }\end{array}$ \\
\hline NFI & 0,797 & $\begin{array}{ll}\text { (Un } \quad \text { Fit) } & 0 \\
\text { s.d. } 1 & \text { (Fit) } \\
\geq 0,90 & \\
\end{array}$ & $\begin{array}{l}\text { Model Fit karena hasil } \\
\text { NFI masih ada di dalam } \\
\text { range }\end{array}$ \\
\hline PNFI & 0,684 & $\begin{array}{l}\text { Semakin } \\
\text { tinggi } \\
\text { semakin baik } \\
>0,600 \text { (Fit) }\end{array}$ & $\begin{array}{l}\text { Model Fit karena hasil } \\
\text { NFI masih ada di dalam } \\
\text { range }\end{array}$ \\
\hline
\end{tabular}

Berdasarkan hasil uji yang tidak sesuai hanya RMSEA. Peneliti melakukan pengujian tahap yang kedua dikarenakan korelasi antara variabel masih ada yang tidak sesuai.

Berdasarkan hasil pengujian variabel risk tidak berpengaruh signifikan, bila ditelaah responden sudah trust dengan Google Drive sehingga indikator risiko dapat diterima oleh responden, kemudian kemudahan (PEOU) tidak signifikan mempengaruhi perilaku dikarenakan Google Drive aplikasi yang sudah dipahami penggunanya untuk bertukar data dan kegunaan (PU) Google Drive bukan hal primer tapi ada kalanya digunakan untuk beberapa hal yang diperlukan pengguna.

Setelah dilakukan pengujian model penelitian modifikasi dengan menghilangkan variabel yang ditolak dan tidak berpengaruh signifikan didapatkan model penelitian sebagai berikut : 
Gambar 9 Model fit yang baik menunjukan score yang lebih kecil dari model sebelumnya. Modifikasi model penelitian adalah sebagai berikut :

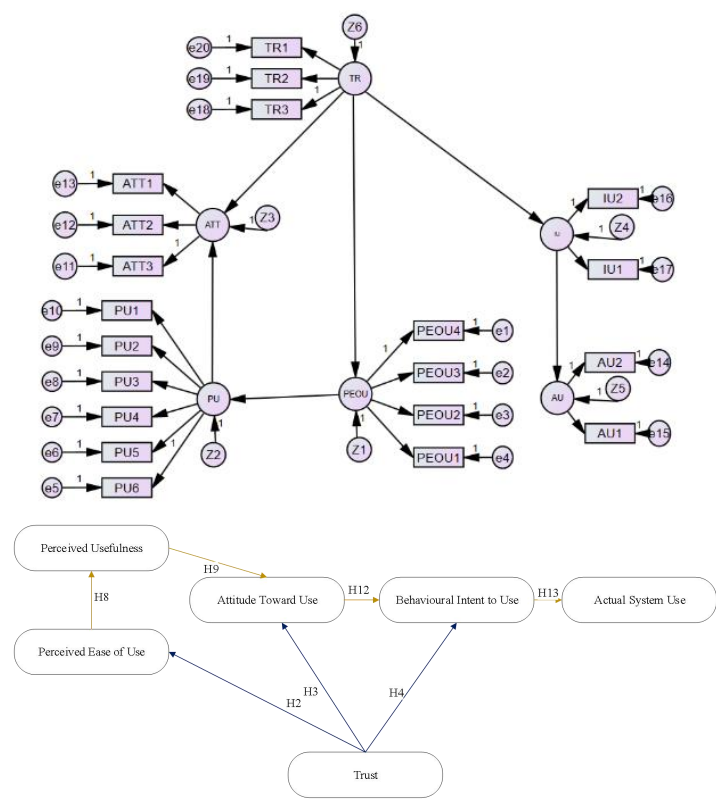

Gambar 9 Modifikasi Model Penelitian

Peneliti mencari Model fit untuk penelitian pengguna Google Drive digambarkan pada gambar 9. Perbandingan Hasil Uji Model Penelitian sebelum dan setelah modifikasi pada TABEL IV :

TABEL IV PERBANDINGAN HASIL UJI MODEL PENELITIAN SEBELUM DAN SETELAH MODIFIKASI

\begin{tabular}{|c|c|c|c|c|}
\hline $\begin{array}{c}\text { Kriteria } \\
\text { Model } \\
\text { sesuai } \\
\text { (Fit) } \\
\end{array}$ & Model Fit & $\begin{array}{c}\text { Hasil } \\
\text { sebelum } \\
\text { modifikasi }\end{array}$ & $\begin{array}{c}\text { Hasil } \\
\text { setelah } \\
\text { modifikasi }\end{array}$ & Evaluasi \\
\hline $\begin{array}{l}\text { Chi } \\
\text { Square } \\
\end{array}$ & $\begin{array}{l}\text { diharapkan } \\
\text { lebih kecil }\end{array}$ & 252,365 & 194,883 & - \\
\hline CMIN/DF & $\begin{array}{l}<5 \text { (Wheaton, } \\
1977 \text { ) } \\
\text { nilai positif }\end{array}$ & 2,429 & 2,942 & Fit \\
\hline GFI & $\begin{array}{l}\text { (Un Fit) } 0 \text { s.d. } \\
1 \text { (Fit) }\end{array}$ & 0,745 & 0,738 & Fit \\
\hline AGFI & $\begin{array}{l}\text { (Un Fit) } 0 \text { s.d. } \\
1 \text { (Fit) }\end{array}$ & 0,675 & 0,664 & Fit \\
\hline RMSEA & $\begin{array}{lr}\leq & 0,08 \\
\text { (Browne } & \text { dan } \\
\text { Curdeck } & , \\
1993) & \\
\end{array}$ & 0,111 & 0,129 & Tidak Fit \\
\hline TLI & $\begin{array}{l}\text { (Un Fit) } 0 \text { s.d. } \\
1 \text { (Fit) }\end{array}$ & 0,846 & 0,836 & Fit \\
\hline NFI & $\begin{array}{l}\text { (Un Fit) } 0 \text { s.d. } \\
1 \text { (Fit) }\end{array}$ & 0,797 & 0.802 & Fit \\
\hline PNFI & $>0,600$ (Fit) & 0,684 & 0,692 & Fit \\
\hline
\end{tabular}

Hasil uji penelitian TABEL IV berdasarkan data 118 responden, jika melihat salah satu syarat penggunaan SEM sampling harus berjumlah 200 sampai dengan 400. Hal ini menyebabkan nilai $C h i$ Square dan RMSEA lebih tinggi dari Model Fit akan tetapi kriteria Model Fit lainnya memenuhi, yaitu DF, GFI, AGFI, TLI, NFI, PNFI. Dengan demikian modifikasi model penelitian ini dapat disimpulkan Baik (Fit).

\section{KESIMPULAN DAN SARAN}

Berdasarkan hasil penelitian Google Drive merupakan aplikasi yang mudah digunakan dan memiliki sehingga mempengaruhi perilaku penggunanya. Trust memiliki pengaruh terhadap manfaat dan perilaku, sedangkan untuk pengaruh TAM pengaruh kemudahan mempengaruhi manfaat masih terbukti sampai dengan penelitian ini. Fenomena yang muncul dari penelitian ini adalah Risk tidak memiliki pengaruh pada variabel lainnya. Sehingga dapat disimpulkan faktor Trust memiliki peranan besar pada Google Drive. Google Drive dipublikasikan dan dikembangkan oleh perusahaan world wide, yaitu Google. Apabila melihat perusahaan yang menaungi Google Drive mungkin mempengaruhi pandangan pengguna Google Drive sehingga risiko yang kemungkinan terjadi pun akan diterima oleh pengguna, dikarenakan pengguna menyakini hanya risiko yang tidak disignifikan yang akan muncul. Sedangkan pengaruh TAM sangat kuat terpengaruhi oleh Trust. Penelitian yang terkumpul menunjukan responden yang merasa antusias dan senang karena kemudahan dari sistem, sehingga mereka mendapatkan manfaat yang membuat pengguna menggunakan Google Drive secara berulang untuk menunjang aktivitas dan meningkatkan produktifitas.

Penelitian ini tentunya dapat dikembangkan lagi ke depannya dengan menambah jumlah responden dan menelaah variabel dan indikator lain yang kemungkinan berpengaruh untuk Google Drive.

\section{REFERENSI}

[1] B. G. Ferdira, A. P. N. Gulo, Y. I. D. Nugroho, and J. F. Andry, "ANALISIS PERILAKU PENGGUNA APLIKASI MOBILE MATAHARIMALL.COM MENGGUNAKAN TECHNOLOGY ACCEPTANCE MODEL (TAM)," $J$ SITECH Sist. Inf. dan Teknol, 2019, doi: 10.24176/sitech.v1i2.2790.

[2] S. Ismulyaty and W. Siswantini, "PENGARUH TRUST, RISK AND TECHNOLOGY ACCEPTANCE MODELS TERHADAP KEPUTUSAN NASABAH DENGAN MINAT NASABAH SEBAGAI VARIABEL INTERVENING," EKOMBIS Rev. J. Ilm. Ekon. dan Bisnis, 2017, doi: 10.37676/ekombis.v5i1.324.

[3] R. Buyya, J. Broberg, and A. Goscinski, Cloud Computing. Principles and Paradigms. 2011.

[4] M. Kholil and S. Mu'min, "Pengembangan Private Cloud Storage sebagai Sentralisasi Data Universitas Nahdlatul Ulama Sidoarjo Berbasis Open Source Owncloud," Ilmu Komput. Dan Desain Komun. Vis., 2018.

[5] P. Lai, "THE LITERATURE REVIEW OF 
TECHNOLOGY ADOPTION MODELS AND THEORIES FOR THE NOVELTY TECHNOLOGY," $J$. Inf. Syst. Technol. Manag., 2017, doi: 10.4301/s180717752017000100002 .

[6] S. Fuad, M. Sangen, and S. A. Albushari, "PENDEKATAN TECHNOLOGY ACCEPTANCE MODEL (TAM) DAN PERCEIVED RISK UNTUK MENGIDENTIFIKASI FAKTOR-FAKTOR YANG MEMPENGARUHI PERILAKU BELANJA ONLINE DI KALIMANTAN," JWM (Jurnal Wawasan Manajemen), 2019, doi: 10.20527/jwm.v6i3.171.

[7] V. Venkatesh, S. A. Brown, and Y. W. Sullivan, "Guidelines for conducting mixed-methods research: An extension and illustration," J. Assoc. Inf. Syst., 2016, doi: 10.17705/1jais.00433.

[8] T. Teo and J. Noyes, "Explaining the intention to use technology among pre-service teachers: a multi-group analysis of the Unified Theory of Acceptance and Use of Technology," Interact. Learn. Environ., 2014, doi: 10.1080/10494820.2011.641674.

[9] J. Nawawi, “ANALISIS PERCEIVED USEFULNESS, PERCEIVED RISK DAN TRUST TERHADAP PEMANFAATAN ATM BAGI NASABAH (Studi Pada Bank BNI di Semarang)," 2012.

[10] Vanidyatama, "Pengaruh Perceived Usefulness, Perceived Ease of Use dan Perceived Risk terhadap Intention to Transact pada Aplikasi Tiket.com di Indonesia," Bank. Manag. Rev., 2012

[11] T. Loanata and K. G. Tileng, "Pengaruh Trust dan Perceived Risk pada Intention To Use Menggunakan Technology Acceptance Model (Studi Kasus Pada Situs ECommerce Traveloka)," Juisi, 2016.

[12] K. M. S. Faqih, "Integrating perceived risk and trust with technology acceptance model: An empirical assessment of customers' acceptance of online shopping in Jordan," 2011, doi: 10.1109/ICRIIS.2011.6125686.

[13] Sugiyono, "Metode Penelitian Pendidikan Pendekatan Kuantitaif, Kualitatif, dan R\&DSugiyono. 2013. 'Metode Penelitian Pendidikan Pendekatan Kuantitaif, Kualitatif, dan R\&D.' Metode Penelitian Pendidikan Pendekatan Kuantitaif, Kualitatif, dan R\&D. https://doi.org/10.1," Metode Penelitian Pendidikan Pendekatan Kuantitaif, Kualitatif, dan R\&D. 2013, doi: 10.1007/s13398-0140173-7.2.

[14] U. Sekaran and R. Bougie, Reserach Methods for Bussiness A Skill-Bulding Approach. 2016.

[15] J. Sarwono, Metode Penelitian Kuantitatif dan Kualitatif. 2006.

[16] G. J. Macfarlane et al., "The prevalence and management of low back pain across adulthood: Results from a population-based cross-sectional study (the MUSICIAN study)," Pain, vol. 153, no. 1, pp. 27-32, Jan. 2012, doi: 10.1016/j.pain.2011.08.005.

[17] Z. Mustafa EQ, Mengurai Variabel Hingga Instrumentasi. 2009.

[18] S. Wijanto, "Structural Equation Modeling dengan LISREL 8,8: Konsep dan Tutorial.," vol. 53, no. 9, 2008, p. 287.

[19] K. Juhri and C. K. Dewi, "Kepercayaan Dan Penerimaan Layanan Mobile Money T-Cash Di Bandung Dengan Pendekatan Technology Acceptance Model ( Tam ), $J$. Pro Bisnis, 2017.

[20] S. Retnosari, "ANALISIS PERCEIVED USEFULNESS, PERCEIVED RISK DAN TRUST TERHADAP PEMANFAATAN ATM BAGI NASABAH (Studi Pada Bank Sumsel babel Syariah)," p. 77, 2015.

[21] W. N. Syahril and B. Rikumahu, "Penggunaan Technology Acceptance Model (Tam) dalam Analisis Minat Perilaku Penggunaan E-Money pada Mahasiswa Universitas Telkom," J. Mitra Manaj. (JMM Online ), 2019.

[22] E. Yani, A. F. Lestari, H. Amalia, and A. Puspita, "Pengaruh Internet Banking Terhadap Minat Nasabah Dalam Bertransaksi Dengan Technology Acceptance
Model," J. Inform., 2018, doi: 10.31311/ji.v5i1.2717.

[23] P. . Jogianto Hartono, MBA, Akt, Sistem Teknologi Komputer. 2004

[24] C. Gardner and D. L. Amoroso, "Development of an instrument to measure the acceptance of internet technology by consumers," 2004, doi: 10.1109/hicss.2004.1265623.

[25] A. Wibowo, "Kajian Tentang Perilaku Pengguna Sistem Informasi Dengan Pendekatan Technology Acceptance Model ( TAM )," Konf. Nas. Sist. Inf., 2017. 